\title{
ANTIBACTERIAL ACTIVITY OF Samanea saman LEAF ETHANOL EXTRACT AGAINST Escherichia coli AND Staphylococcus aureus AND ITS TOTAL FLAVONOID AND PHENOLIC CONTENTS
}

\author{
W. S. Rita ${ }^{1^{*}}$, I M. D. Swantara ${ }^{2}$, I. A. R. Astiti Asih ${ }^{1}$, N. K. Sinarsih ${ }^{2}$ \\ ${ }^{1}$ Department of Chemistry, Faculty of Mathematics and Natural Sciences, Universitas Udayana, Bukit \\ Jimbaran, Badung, Bali \\ ${ }^{2}$ Department of Applied Chemistry, Faculty of Mathematics and Natural Sciences, \\ Universitas Udayana, Denpasar, Bali \\ *E-mail: susanah.rita@unud.ac.id
}

\begin{abstract}
Antibacterial activity of Samanea saman usually shows a positif correlation to the flavonoid and phenolic contents. The aim of this study was to evaluate the antibacterial activity of the ethanol extract of Samanea saman against Escherechia coli and Staphylococcus aureus and determine the total flavonoid and phenolic contents of the extract. The extraction was done by ethanol $96 \%$ at room temperature. The antibacterial assay was conducted by agar disc diffusion method. The total flavonoid and phenolic contents were determined by UV-Vis Spectrofotometer with the standard of quersetin and galic acid, respectively. The extraction of $250 \mathrm{~g}$ of Samanea saman leaves resulted in $24.5 \mathrm{~g}$ of ethanol extracts. The ethanol extract showed a moderate inhibition of $8.33 \mathrm{~mm}$ towards E. coli and a strong inhibition of $13.6 \mathrm{~mm}$ towards $S$. aureus at the concentration of $4 \%$. The Minimum Inhibitory Concentration (MIC) of the extract against E. coli and S.aureus were of $3 \%$ and $0.3 \%$, respectively. The total flavonoid and phenolic contents were successively $1233.2991 \mathrm{mg} \mathrm{QE} / 100 \mathrm{~g}$ and $2544.6154 \mathrm{mg} \mathrm{GAE} / 100 \mathrm{~g}$.
\end{abstract}

Keywords: Escherechia coli, flavonoid and phenolic content, Samanea saman, Staphylococcus aureus

\section{INTRODUCTION}

Infection is one of the most common health problems suffered by the community. Infection is an invasion of the body by microorganisms and proliferates in body tissues that cause pain. The development of tropical Indonesian infections is due to moist air, poor sanitation, densely populated environments and favorable temperatures for the development of microorganisms. One type of microorganism that can cause infection is bacteria. The bacteria that cause the most infection cases in the community are pathogenic bacteria from Staphylococcus aureus (S. aureus) and Escherichia coli (E. coli) species.

E. coli is a pathogenic bacteria that can infect any tissue or body tool and cause disease with typical signs of inflammation, necrosis, and abscess formation (Jawetz et al., 1995) While $S$. aureus can cause infectious diseases such as ulcers, acne, impetigo, and severe infections such as pneumonia, mastitis, plebitis, meningitis, urinary tract infections, osteomyelitis, and endocarditis. S. aureus is also a major cause of nosocomial infections, food poisoning, and toxic shock syndrome (Mandal, 2012).

Synthetic medicines, such as antibiotic, commonly used to overcome a diseases caused by $E$. coli and $S$. aureus, but these medicines can be resistant to the bacteria. Frieri et al. (2017) reported that multidrug resistant patterns in Grampositive and -negative bacteria have resulted in difficult-to-treat or even untreatable infections with conventional antimicrobials. Therefore, an active ingredient of antibacterial plant extract is required. One of these plants is rain tree (Samanea saman).

Rain tree in Indonesia are used as shade trees and urban forests (Santosa et al., 2012; Dahlan, 2010). The rain tree leaf water extract was reported to inhibit the growth of $E$. coli at minimum concentration of $0.5 \%$ and to S.aureus at 1\% (Prasad et al., 2008). Methanol extracts of rain tree have antibacterial activity with inhibition zones ranging from $11 \mathrm{~mm}$ to $3.5 \mathrm{~mm}$ at $1 \mathrm{mg}$ / $\mathrm{mL}$ concentration (Thippeswamy et al., 2012). Rain tree leaf ethanol extract inhibited the growth 
of Fusarium solani, pathogenic fungi causing stem rot diseases on dragon fruits (Rita et al., 2016a; Rita et al., 2013). Methanol extract of S. saman showed measurable inhibitory activity against both $S$. aureus and B. subtilis (Obasi et al., 2010). Butanol extract of rain tree leaf collected from Bali could strongly inhibit $S$. aureus while the inhibition zone of the extract against $E$. coli was moderate at concentration of $8 \%$ (Rita et al., 2016b).

Antimicrobial activity of a material was associated with its chemical content, such as flavonoid and phenolic content. Mahboubi et al. (2015) evaluated total flavonoid and phenolic contents from extract of Punica granatum L. flowers and its antibacterial activity towards both Gram positive and Gram negative bacteria causing food poisoning. The total flavonoid and phenolic content was positively associated with the antibacterial activities. Phenolic and flavonoid contents of leaf extract of ten Algerian Ficus carica L. varieties have been investigated by Mahmoudi et al. (2016), the extracts have an antimicrobial effect against Bacillus cereus and Staphylococcus aureus. This study aimed to evaluate the antibacterial activity of ethanol extract of Samanea saman against Escherechia coli and Staphylococcus aureus and to determine the total flavonoid and phenolic contents of the extract.

\section{MATERIAL AND METHODS}

\section{General Experimental Procedure}

The study was initiated with the extraction of plant material, followed by antibacterial assay. After that, the total of flavonoids and phenolic content were determined by Spectrofotomer UVvis.

\section{Plant material}

The sample of rain tree leaves (Samanea saman) were collected from around Denpasar Bali. The tree was identifid at LIPI-UPT Center for Plant Conservation Botanical Garden "Eka Karya" Bali. The leaves were dried at room temperature for 15 days and were powdered and stored for further analysis.

\section{Bacterial Agents}

The ethanol extract of rain tree leaves was assayed against two strains bacteria, Escherichia coli (Gram-negative) and Staphylococcus aureus (Gram-positive). These microorganisms were obtained from culture collection of Laboratory of Microbiology Department of Biology, Faculty of Mathematic and Natural Sciences, Udayana University. The isolates were purified and maintained at $4{ }^{\circ} \mathrm{C}$ until used.

\section{Plant extraction}

Around $250 \mathrm{~g}$ of rain tree leaf powder was extracted with $5 \mathrm{~L}$ of $70 \%$ ethanol for $24 \mathrm{~h}$ at room temperature $\left(25{ }^{\circ} \mathrm{C}\right)$. The extract was filtered through Whatman No. 4 filter paper, evaporated to dryness under vacuum and stored at $4{ }^{\circ} \mathrm{C}$ until analysis.

\section{Antibacterial Activity Assay}

Antibacterial activity assay of the rain tree leaf extract was carried out by disc diffusion method at concentrations of $4 \%$ with three repetitions (Sinarsih et al., 2016). The negative control used was the solvent of the extract. While positive controls are amoxicillin for $S$. aureus and meropenem for $E$. coli which were already available in paper disc form.

The assay was initiated with media preparation, $20 \mathrm{~mL}$ of Mueller-Hinton Nutrient Agar (NA) medium inserted into a sterile petri dish then closed and cooled to solidify. A hundread $\mu \mathrm{L}$ of suspension, having $10^{8} \mathrm{CFU} / \mathrm{mL}$ of bacterial strains was dispensed on the medium using sterile cotton. The medium was then allowed to dry slightly about 5-8 minutes before the disc was attached.

As much as $20 \mu \mathrm{L}$ the extract was dropped on disc paper with a diameter of $6 \mathrm{~mm}$ using a micropipette, and for negative controls, solvent was dropped at the same volume. The disc papers were then allowed to stand for \pm 120 minutes. The disc paper containing extract, positive control, and negative control was then placed on top of bacterial media with tweezers. Then the media was incubated at the optimum growth temperature of $S$. aureus and E. coli which ranged from $35-37{ }^{\circ} \mathrm{C}$ for 24 hours. The inhibitory diameters of extract were measured after the incubation period.

Minimum inhibitory concentration (MIC) was determined at various concentrations. There were $0 ; 0.1 ; 0.2 ; 0.3 ; 0.4 ; 0.5 ; 1 ; 1.5 ; 2 ; 2.5 ; 3 ; 3.5$; 
And $4 \%$. The concentration specified as MIC was the smallest concentration that still had the ability to inhibit bacterial growth.

\section{Determination of Total Flavonoid and Phenolic Contents}

Total Flavonoid contents

Total flavonoids were determined by aluminum chloride method (Rita et al., 2016b). A total of 0.0417 grams of samples were dissolved in $50 \%$ ethanol to $5 \mathrm{~mL}$ volume, homogenized, and centrifuged at $3000 \mathrm{rpm}$ for $15 \mathrm{~min}$. The filtrate was taken $25 \mu \mathrm{L}$, then diluted to $500 \mu \mathrm{L}$ volume. The solution was added with $2 \% \mathrm{AlCl}_{3}(500 \mu \mathrm{L})$ so the total volume of the solution became $1000 \mu \mathrm{L}$. The mixture was allowed to stand for 90 minutes before the absorbance was measured at a wavelength of $415 \mathrm{~nm}$. The total flavonoid contents were expressed as $\mathrm{mg}$ quercetin equivalents $/ 100 \mathrm{mg}$ extract. The total flavonoids can be calculated by the following formula:

$$
F 1=\frac{C \cdot V \cdot F \cdot 10^{-6}}{m} 100 \%
$$

where: $\mathrm{F} 1=$ total flavonoids, $\mathrm{C}=$ equality of quercetin $(\mathrm{g} / \mathrm{mL}), \mathrm{V}=$ total volume of extract $(\mathrm{mL})$, $\mathrm{F}=$ the dilution factor, $\mathrm{m}=$ weight of sample $(\mathrm{g})$

\section{Total Phenolic contents}

Total phenolic contents were determined using Folin-Ciocalteu reagent (Thippeswamy et al., 2011; Qadir et al., 2017). A total of 0.025 gram samples were dissolved in $80 \%$ methanol to obtain volume of $5 \mathrm{~mL}$, homogenized, and centrifuged at $3000 \mathrm{rpm}$ for $15 \mathrm{~min}$. The filtrate was taken $10 \mu \mathrm{L}$, then diluted to $100 \mu \mathrm{L}$ volume, added with $100 \mu \mathrm{L}$ Folin-Ciocalteu reagent, and $800 \mu \mathrm{L}$ of $5 \%$ sodium carbonate so the total solution volume becomes $1000 \mu \mathrm{L}$. The mixture was allowed to stand for 90 minutes before the absorbance was measured at a wavelength of $760 \mathrm{~nm}$. The total phenolic contents were expressed as mg gallic acid equivalents /100 $\mathrm{g}$ of extract. The total phenols can be calculated by the following formula:

$$
F 2=\frac{C \cdot V \cdot F \cdot 10^{-6}}{m} 100 \%
$$

where: $\mathrm{F} 2=$ total phenol, $\mathrm{C}=$ equality of gallic acid $(\mathrm{g} / \mathrm{mL}), \mathrm{V}=$ total volume of extract $(\mathrm{mL}), \mathrm{F}=$ the dilution factor, $\mathrm{m}=$ weight of sample $(\mathrm{g})$

\section{RESULTS AND DISCUSSION}

The extraction of $250 \mathrm{~g}$ of rain tree leaf powder resulted in $24.5 \mathrm{~g}$ of ethanol extract. Antibacterial activity assay against $E$. coli and $S$. aureus of rain tree leaf ethanol extract was performed at a concentrations of $4 \%$ with a positive control of meropenem for $E$. coli and amoxicillin for $S$. aureus. Antibacterial assay results are shown in Table 1.

Table 1. Antibacterial Activity of the ethanol extract of Samanea saman leaves against E. coli and S. aureus

\begin{tabular}{cccc}
\hline \multirow{2}{*}{ Bacteria } & \multicolumn{3}{c}{ Avarage of Inhibition Zone (mm) } \\
& $\begin{array}{c}\text { Positive } \\
\text { control* }\end{array}$ & $\begin{array}{c}\text { Negative } \\
\text { control }\end{array}$ & $\begin{array}{c}\text { Ethanol Extract } \\
(4 \%)\end{array}$ \\
\hline E. coli & 32.33 & - & 8.33 (moderate) \\
S. & 19.67 & - & 13.67 (strong)
\end{tabular}

aureus

*Meropenem (for E.coli) and Amoxycilin (for S. aureus)

From Table 1, it can be seen that ethanol extract of rain tree leaf could inhibit the growth of E. coli with moderate inhibition of $8.33 \mathrm{~mm}$, while it could inhibit the growth of $S$. aureus with strong inhibition of $13.67 \mathrm{~mm}$. According Davis and Stout (1971), if the extract gave an inhibition zone diameter of less than $5 \mathrm{~mm}$, it was categorized as weak inhibition, between 5 and $10 \mathrm{~mm}$ was moderate inhibition, larger than 10 to $20 \mathrm{~mm}$ was strong, and higher than $20 \mathrm{~mm}$ was very strong inhibition. From this data, it can be shown that $S$. aureus (gram positive bacteria) was more sensitive to the extract than E.coli (gram negative bacteria). The different capabilities of the extract in inhibiting the growth of bacteria from different classes may be due to differences in the complexity of cell wall constituent of both types of bacteria (Pelczar et al., 2010).

Gram-negative bacteria have a way of protecting their cell membranes from penetrating antibacterial agents, since they have a unique outer membrane. Gram-negative bacteria have cell walls with relatively thinner peptidoglycan layers, and 
periplasmic space between cell walls and membranes. In addition, the structure of Gramnegative bacterial membrane contains Lipopolysaccharide (LPS) or endotoxin which is a complex structure of Lipid A, short chain of sugar, and long chain carbohydrates. Polysaccharides play a role in the selective entry of hydrophobicity into cell membranes, whereas lipid properties play a role in the inclusion of hydrophilic compounds (Jawetz et al., 1995; Pelczar et al., 2010).

Gram-positive cell wall is structured by a simpler peptidoglycan layer compare to the more complex Gram-negative structure. These cause that the antibacterial compounds are more easily enter into the cell and find the target. The presence of the ability of antibacterial compounds in damaging the cell wall of bacteria causes the disruption of cell wall function as a giver of cell shape and protect cells from lysis can cause bacterial death (Dewi, 2013; Brown et al., 2015).

MIC was determined to recognize the smallest concentration that still had the ability to inhibit bacterial growth. It was performed at various concentrations of $0 ; 0.1 ; 0.2 ; 0.3 ; 0.4 ; 0.5$; $1 ; 1.5 ; 2 ; 2.5 ; 3 ; 3.5 ;$ and $4 \%$. The result demonstrated that MIC of the extract to inhibit the growth of E. coli and S. aureus were 3\% and $0.3 \%$ respectively, with the inhibition zone of 6.50 and $6.42 \mathrm{~mm}$ (Figure 1 and Table 2).

These values (from Table 2) indicated that the rain tree leaf ethanol extract was ten times more effective in inhibiting the growth of $S$. aureus compared to E. coli. The Data also shows that the inhibitory zone increased with the increase of extract concentration. These results were consistent with the statements of Rhoades et al. (2000) that in general the inhibitory zone tends to increase with the increase of extract concentration. With the increasing concentration of extracts, the content of active compounds was greater so that the ability of extract inhibiting the growth of bacteria were greater. However, inhibition of ethanol extract toward $S$. aureus, at concentration of 2 and $2.5 \%$ were not significantly different as well as that at concentration of 0.3 and $0.4 \%$ ( $<$ < $5 \%)$. (a)

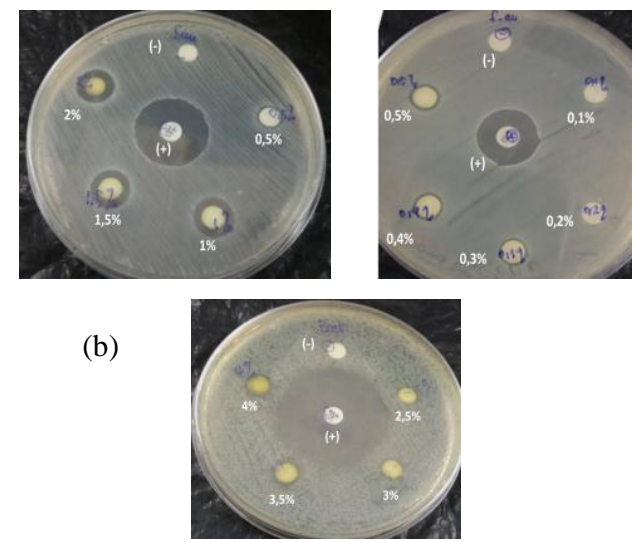

Figure 1. Inhibition zone of rain tree Leaf ethanol Extract at various concentrations. (a) S. aureus, (b) E. coli

Table 2. Inhibition zone of the growth of E. coli and $S$. aureus of rain tree leaf ethanol extract at various concentrations

\begin{tabular}{ccc}
\hline Treatment & \multicolumn{2}{c}{$\begin{array}{c}\text { Avarage of Inhibition } \\
\text { Zone }(\mathrm{mm})\end{array}$} \\
$(\%)$ & E. coli & S. aureus \\
\hline 4.0 & $8.17^{\mathrm{a}^{*}}$ & $13.33^{\mathrm{a}^{*}}$ \\
3.5 & $7.17^{\mathrm{b}}$ & $12.67^{\mathrm{b}}$ \\
3.0 & $6.50^{\mathrm{c}}$ & $12.17^{\mathrm{bc}}$ \\
2.5 & - & $11.83^{\mathrm{c}}$ \\
2.0 & - & $11.67^{\mathrm{c}}$ \\
1.5 & - & $10.67^{\mathrm{d}}$ \\
1.0 & - & $9.50^{\mathrm{e}}$ \\
0.5 & - & $7.67^{\mathrm{f}}$ \\
0.4 & - & $6.92^{\mathrm{g}}$ \\
0.3 & - & $6.42^{\mathrm{g}}$ \\
0.2 & - & - \\
0.1 & - & - \\
0 & - & -
\end{tabular}

*Values followed by the same letters in the same column are not significantly different according to the Duncan's Multiple Range Test at $P<5 \%$.

The calibration curve for the determination of flavonoid and phenolic contents were presented at Figure 2. Based on the calibration equation of quercetin, $\mathrm{y}=0.070 \mathrm{x}-0.032$ and that of gallic acid, $\mathrm{Y}=0.013 \mathrm{x}-0.001$, total flavonoid and phenolic contents could be determined using equations 1 and 2 . The calculation was summarized at Table 3. From the Table 3, it could be seen that the total flavonoid and phenolic 
contents were successively $1233.2991 \mathrm{mg}$ QE/100g and $2544.6154 \mathrm{mg} \mathrm{GAE} / 100 \mathrm{~g}$ extract.

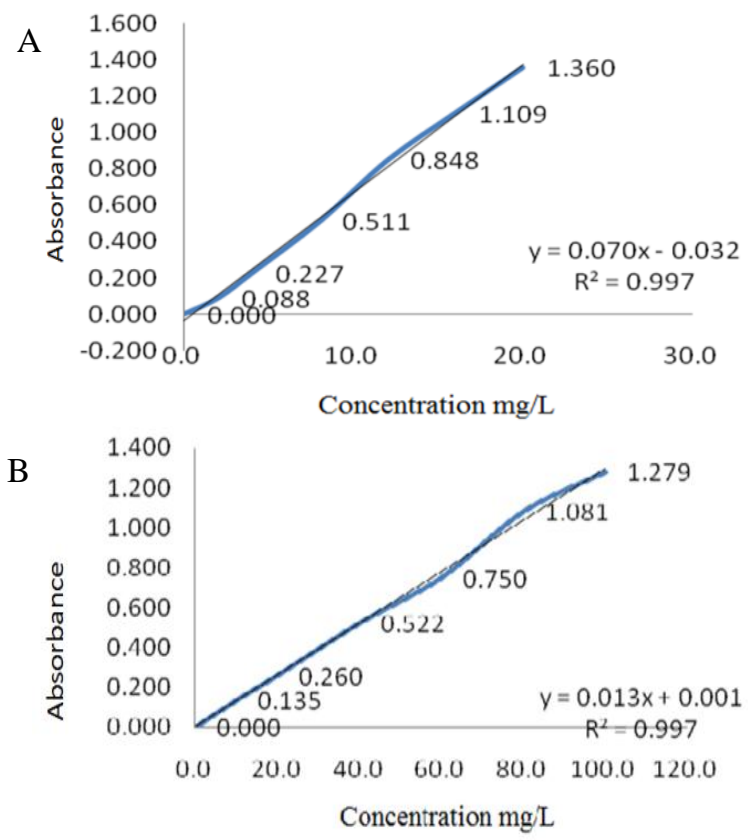

Figure 2. Calibration curve of A) Standard Quercetin B) Standard Galic acid

The data shows that the total flavonoid and phenolic contents of ethanol extract of rain tree leaf were quite high. This is related to the activity as an antibacterial. Mahboubi et al. (2015) stated that the antimicrobial efficacy of the herbal extracts correlates with their flavonoid contents.

Table 3. Total flavonoid and phenolic compounds of rain tree leaf ethanol extract

\begin{tabular}{ccc}
\hline & Flavonoids & Phenolics \\
\hline Weigh of sample $(\mathrm{g})$ & 0.0417 & 0.025 \\
Absorbance $(\mathrm{Y})$ & 0.3280 & 0.1664 \\
Concentration $(\mathrm{mg} / \mathrm{mL})$ & 5.1429 & 12.7231 \\
Volume $(\mathrm{mL})$ & 5 & 5 \\
Dilution & 20 & 10 \\
Contents \% & 1.23 & 2.54 \\
$\mathrm{mg} / 100 \mathrm{~g}$ & 1233.2991 & 2544.6154 \\
\hline
\end{tabular}

Flavonoids are the result of plant metabolism that generally serves as a response to microbial infections. The theory of flavonoid mechanisms as antibacterial is similar to other phenolic compounds such as tannins in inhibiting bacterial growth, through the formation of bonds with bacterial proteins through hydrogen bonding, and the formation of covalent bonds (Cushnie and Lamb, 2005; Kumar et al., 2013). In addition, the mechanism of action that may occur is inactivation due to the presence of hydrogen bonds that result in cell wall protein structures and unstable cytoplasmic membranes. The instability causes selective permeability, active transport function, the control of the protein structure of the bacterial cell becomes disturbed, resulting in loss of macromolecules and ions from the cell, so that the bacterial cells lose their shape and undergo lysis (Pelczar et al., 2010; Naufalin and Herastuti, 2017).

\section{CONCLUSION}

Based on our study, it could be concluded that ethanol extract of rain tree (Samanea saman) leaf showed good antibacterial activities against $S$. aureus and moderate activity against $E$. coli which suggest that this plant could be used to treat various infections caused by bacteria. This activity is closely related to the total flavonoid and phenol contents.

\section{ACKNOWLEDGEMENT}

This work was supported by a grant from Research Technology and Higher Education Republic of Indonesia. We wish to express our gratitude to the Head of Research and Community Institutions of Udayana University for facilitating all the needs for the research.

\section{REFERENCES}

Brown, L., Wolf, J. M., Prados-Rosales, R., Casadevall, R., 2015, Through the wall: extracellular vesicles in Gram-positive bacteria, mycobacteria and fungi, Nature Rev. Microbiol, 13: 620-630.

Cushnie, T.P.T and Lamb, A.J., 2005, Antimicrobial Activity of Flavonoids. Int J Antimicrob Agents, 26: 343-356. 
Dahlan, E., 2010, Trembesi Dahulunya Asing Namun Sekarang Tidak Lagi, IPB press. Bogor.

Davis, W.W. and Stout, T.R., 1971, Disc Plate Method Of Microbiological Antibiotic Essay, J. Appl. Microbiol, 22(4): 659665.

Dewi, A.K., 2013, Isolasi, Identifikasi dan Uji Sensitivitas Staphylococcus aureus terhadap Amoxicillin dari Sampel Susu Kambing Peranakan Ettawa (PE) Penderita Mastitis di Wilayah Girimulyo, Kulonprogo, Yogyakarta, Jurnal Sain Veteran, 31(2): 130-138.

Frieri, M., Kumar, K., Boutin, A., 2017, Antibiotic resistance, J Infect Public Health, 10: 369-378.

Jawetz, E., Melnick, J. L., Adelberg, E. A., Brooks, G. F., Butel, J. S., Ornston, L. N., 1995, Medical Microbiology, ed. 20, University of California, San Fransisco.

Kumar, Ravi A., Shaik, R., Yeshwanth, D., 2013, Phytochemical Evaluation of Delonix Regia Samanea Saman Bauhinia Variegatga. IJRPC, 3(4):768-772.

Mahboubi, A., Asgarpanah, J., Sadaghiyani, P.S., Faizi, M., 2015, Total phenolic and flavonoid content and antibacterial activity of Punica granatum $\mathrm{L}$. var. pleniflora flowers (Golnar) against bacterial strains causing foodborne diseases. BMC Complement Altern Med., 15: 366.

Mahmoudi, S., Khali, M., Benkhaled, A., Benamirouche, K., Baiti, I., 2016, Phenolic and flavonoid contents, antioxidant and antimicrobial activities of leaf extracts from ten Algerian Ficus carica L. Varieties, Asian Pac. J. Trop. Biomed, 6(3): 239-245.

Mandal, A., 2012, What is Staphylococcus Aureus? [cited 18 July 2015]. Available from: http://www.newsmedical.net/health/ What-is-StaphylococcusAureus.aspx.

Naufalin, R., Herastuti, S.R., 2017, Antibacterial activity of Nicolaia speciosa fruit extract, Int. Food. Res. J., 24(1): 379-385.

Obasi, N. L., Egbuonu, A.C.C., Ukoha, P. O., Ejikeme, P. M., 2010, Comparative phytochemical and antimicrobial screening of some solvent extracts of Samanea saman (fabaceae or mimosaceae) pods. Afr, J. Pure Appl. Chem., 4(9): 206-212.

Pelczar, M.J., Chan, E.C.S. Krieg, N.R., 2010, Microbiology. $5^{\text {th }}$ Ed. Tata McGraw-Hill Education Pvt. Ltd. New Delhi.

Prasad, R.N., Viswanathan,S., Devi, J.R., Nayak, Swetha, V.V.C., Archana, B.R., Parathasarathy, N., and Rajkumar, J., 2008, Short Communication. Preliminary phytochemical screening and antimicrobial activity of Samanea saman, J. Med. Plants Res., 2(10): 268270.

Qadir, M.A., Shahzadi, S.K., Bashir, A., Munir, A., Shahzad, S., 2017, Evaluation of Phenolic Compounds and Antioxidant and Antimicrobial Activities of Some Common Herbs, International J. Anal. Chem., 2017: 1-7.

Rhoades, J., Roller, S., 2000, Antimicrobial actions of degraded and native chitosan against spoilage organisms in laboratory media and foods. Appl. Environ. Microbiol., 66(1): 80-86.

Rita, W.S., Suprapta, D.N., Sudana, I M., Swantara, I M. D., 2013, First Report on Fusarium solani, a Pathogenic Fungus Causing Stem Rot Disease on Dragon Fruits (Hylocereus sp.) in Bali, J. Biol. Agric. Healthc., 3 (17): 93-99.

Rita, W.S., Suprapta, D.N., Sudana, I M., Swantara, I M.D., 2016a, Antifungal Activity of Rain Tree (Samanea saman Jacq.) Leaf Extract Against Fusarium solani, The Cause of Stem Rot Disease on Dragon Fruit (Hylocereus sp.), CoSCI Proceeding, Surabaya.

Rita, W.S., Swantara, I M. D., Asih, I.A.R.A., Sinarsih, N. K., 2016b, Total flavonoid and phenolic contents of n-butanol extract of Samanea saman leaf and the antibacterial activity towards Escherichia coli and Staphylococcus aureus. AIP Conference Proceedings, 1718. Surabaya.

Santoso, S., Lestari, S., Samiyarsih, S., 2014, Pengembangan Sumber Daya Pedesaan 
Antibacterial Activity Of Samanea Saman Leaf Ethanol Extract Against Escherichia Coli And Staphylococcus Aureus And Its Total Flavonoid And Phenolic Contents

(W. S. Rita, I M. D. Swantara, I. A. R. Astiti Asih, N. K. Sinarsih)

dan Kearifan Lokal Berkelanjutan II, 197-203, Proseding Seminar Nasional. Purwokerto.

Sinarsih, N.K., Rita, W.S., Puspawati, N.M., 2016, Uji Efektivitas Ekstrak daun Trembesi (Samanea saman (Jacq.)) sebagai Antibakteri Escherichia coli dan Staphylococcus aureus, Cakra Kimia, 4(2): 129-136.
Thippeswamy, S., Praveen, P., Mohana, D.C., Manjunath, K.., 2011, Antimicrobial Evaluation And Phytochemical Analysis of A Known Medicinal Plant Samanea saman (Jacq.) Merr. Against Some Human and Plant Pathogenic Bacteria and Fungi, Int J Pharma. Bio. Sci.. 2(2): 443-452. 